\title{
Recalling the Term 'World Christianity': Excursions into Worldings of Literature, Philosophy, and History
}

\author{
Dorottya Nagy
}

'Recalling' can be both an act of remembering and of taking back something that is known and used by a broader public, such as the term 'World Christianity', which has been understood in different ways and used for different purposes by an English-speaking and reading public for the last hundred years at least. ${ }^{1}$ It has meant different things for different people in different times, and it continues to create even more new functions when transposed from English into other languages. ${ }^{2}$ In fact, the jury is still out on the necessity of 'World Christianity' being transposed into different languages, especially ones that facilitate communication within the academia, and whether the English term is synonymous with the German term Weltchristentum, the French term Christianisme mondial, or the Portuguese term Cristianismo mundial. ${ }^{3}$ 'World Christianity', in spite of its broad contextual usage, which resulted in the establishment of institutes and chairs at universities, and increased the sales of publishing houses, keeps raising the question, "What do you mean by it?" Even scholars such as Dale Irvin, who were at the cradle of the most recent

1 I thank all my excellent teachers in the field of humanities (literature, philosophy, psychology, art, and history), who taught me that the world is always larger than we think, and in order to grasp something of the world, one must not imagine themselves and their locality to be the centre of the universe.

2 During a conversation about the term, I learned that a Korean theological institute translated 'World Christianity' as 'world church', a transposition of the term that goes against arguments that advocate for critically looking at the concept of church history as a useful concept for historiography (see Phan 2012).

3 Here the issue of transposers also needs to be given attention, and the extent to which a term is being translated or transposed. For example, how does the English- Portuguese book, World Christianity as public religion = Cristianismo mundial como religião pública (2016) edited by Raimundo Barreto et al. address the question of English and non-English conceptualisations of issues the term 'World Christianity' is being used to describe? 
attempts to reconceptualise the term, repeatedly asked themselves, "What is World Christianity?" (Irvin 2016). ${ }^{4}$

Similarly to 'globalisation', 'secularisation', 'cosmopolitanism', and other contemporary buzzwords created and adopted by scholars, 'World Christianity' as a concept/product needs to be regularly recalled, examined, and (re)defined to ensure continued and proper usage. Of course, it is in the nature of such buzzwords to assume different meanings, even when used in a specific context, which means that different understandings of the term may co-exist. Here 'recalling' implies a place where the term can be further refined, and the designation of an agent responsible for ensuring the continued applicability of the term. It is within such a place, within the context of an interdisciplinary academic workshop, that I as a theologian-missiologist seek to explore the functionality of the term 'World Christianity' for theological and missiological research.

This chapter is based on my discussion published in the volume Relocating World Christianity (2017), edited by Joel Cabrita, David Maxwell, and Emma Wild-Wood, in which I assumed a critical distance from arguments that define 'World Christianity' as a field of study, an emerging discipline, or a new phenomenon, and proposed to define it as an approach to the study of Christians and Christian communities worldwide through the categories of connectivity, diversity, unity, and locality. However, assuming such a critical distance does raise the question of why I am interested in the viability and functionality of the term as an approach. The simplest answer to this question is that as a theologian-missiologist interested and engaged in studying Christians and Christian communities worldwide, I seek to connect with scholars who share the same interest. Since much of that interest seems to manifest under the keyword 'World Christianity', I seek ways of contributing to discussions there. To put it differently, discourses captured under the term 'World Christianity' point to the issue of knowledge construction about Christians and Christian communities worldwide, and I wish to investigate the viability of the term for innovatively researching and teaching that which is behind the abstraction called 'Christianity'.

As usage of the term 'World Christianity' is linked to knowledge construction about Christians and Christian communities worldwide, I chose to place

4 On his blog, Thomas Thangaraj posed the question, "What in the world is World Christianity about?" and concluded that World Christianity "is the world-wide Christian community that stands with open arms to welcome anyone from any part of the world to its fellowship, and kneels with bended knee to take its humble yet rightful place among the religions of the world." Source: http://www.bu.edu/cgcm/annual-theme/what-in-the-world-is-world -christianity/, date of access: 13 June, 2018. 
the concept in the category of methodological tools, rather than limit it to a field of study, a discipline, or a phenomenon. In light of this, the question I seek to answer by recalling the term 'World Christianity' for the purposes of the present discussion is this: to what extent may an analysis of 'worldings' ${ }^{5}$ in academic research be useful in further developing 'World Christianity' as an approach for the interdisciplinary study of the complexities of Christians and Christian communities worldwide?

It seems that parallel to the emergence of World Christianity discourses in recent decades, discourses on world literature, world philosophy, and world history have emerged as well. In my previous paper mentioned above, I observed that a rebooting of the term 'World Christianity' went hand in hand with a rebooting of the study of Christianity by social scientists, such as the emergence of the anthropology of Christianity (Robbins 2014; Nagy 2017). Similarly to theological discourses on liberation, apartheid, or in the form of contextual theologies, World Christianity discourses often borrow concepts, theories, and methods from the social sciences, while paying hardly any attention to the humanities and their discourses on worlding.

With reference to the growing body of literature on 'worldings', I argue that in order to develop 'World Christianity' into a methodological approach, we need to look at broader intellectual discourses that emphasise the necessity of world-mindedness. Therefore, in this chapter, I shall first provide a general overview of the usage of 'world' as a modifier in broader intellectual discourses, and then I shall engage in dialogue with conceptualisations of world literature, world philosophy, and world history. I call these sections "excursions," since they only provide a glimpse of what an interdisciplinary engagement with the concept of worlding might have to offer for deepening methodological reflections about researching Christians and Christian communities worldwide through the lens of a World Christianity approach. Following these interdisciplinary excursions, I shall return to the four concepts I introduced earlier as possible keywords for a World Christianity approach, and discuss the ways in which they could be further articulated.

5 Intellectual discourses on worlding usually revolve around Heidegger's verb welten and his preoccupation with Dasein. For that reason, I am grateful to Vladimir Biti (2016) and Rajagopalan Radhakrishnan (2008) for helping me rediscover the term. Biti taught me to think of 'world' as a modifier that is always related to power structures, and from Radhakrishnan's reading of Ranajit Guha's interpretation of Rabindranath Tagore, I learned that worlding happens when the "I exist" and the "I know" come together: "The worlding of the world is simultaneously ontological and epistemological. It takes place in a time alien to historiography: a time that is neither stranded in immanence nor interpellated by any regime of transcendence" (Radhakrishnan 2008: 230). 


\section{Framing Worldings}

Given the importance of the modifier 'world' in conceptualising 'World Christianity', I shall recall the modifier in order to investigate its functionality for studying Christians and Christian communities worldwide. As Dana Robert (already in 200o), Dale Irvin, Peter Phan, and Martha Frederiks (this volume) argue, 'World Christianity' has been present in many theological discourses throughout the twentieth century. Based on their arguments, I postulated that the articulated or less articulated usage of the term goes hand in hand with, and is inseparable from, an intellectual movement, which created the term 'worldmindedness' for the interpretation of socio-political and ideological changes and events that were perceived as world-changing events or processes. Having made this observation, I want to point out the threefold methodological challenge such an intellectual world-mindedness poses for research. Firstly, who determines, and from which segment of the academic endeavour, the ways in which old and existing sources will be reinterpreted and new sources will be identified or generated? Secondly, what happens to the authority of the researcher with regard to sources and their usage? Thirdly, what happens to the authority of the researcher within academic entrepreneurship, which commercialises knowledge (Nyeko and Sing 2015)?

'Alterity' and 'otherness' have become main themes in knowledge construction within the framework of world-mindedness, which addresses the above formulated challenges as conditioned by significant geo-political transformations and accelerated technological developments, which have transformed experiencing time and place, alterity, and otherness. Nevertheless, 'worldmindedness' also generated a set of binaries, which for the last thirty years has heavily influenced research on knowledge construction. Beyond certain old but still favoured binaries, such as the west and the rest, or west and nonwest, we have seen the emergence of new binaries like the global south and the global north, or the global and the local. The latter has been pushed further into the neologism 'glocal' or 'glocalisation', also favoured in theological and missiological research (Schreiter 1997; Satyavrata 2004; Suh 2015). In light of the arguments above, the question of whose terminology and taxonomy will win remains to be seen, because worldings as intellectual exercises also imply complex relations of power between the agents involved in a given research.

Placed in a global context, the modifier 'world' assumes multiple meanings, referring not only to geo-political places, but also to a diversity of perceptions, experiences, and processes of cohabitation within shared localities and beyond. This is why I argue that when placed before 'Christianity', 'world' may refer to parallel worlds within a shared locality, or worlds that are constructed 
and owned by people with different conceptual, ritual, and virtual domains, such as the digital world, the overlapping worlds of particular confessions or movements, or different social worlds (Nagy 2017). In this sense, 'world' relates to the concept of "milieu" as "a live space that conjoins the heterogeneous series of organism and environment through artifices that conduct their mutual eventualities. The milieu is thus not so much a given space, but a space composed through the conjunction of heterogeneous eventualities" (Altamirano 2014: 18).

Phan observes that throughout the theological discourses of the last hundred years, several shifts have occurred in the meaning of the term 'World Christianity'. Phan and Thomas Thangaraj concluded that earlier usages of the term promoted Christian missions and ecumenical unity, while in its present usage, "the expression refers to the historical, sociological, cultural and theological diversity and multiplicity of Christianity, from its very beginning, throughout its two-millennia history, and arguably more so in the future" (Phan 2012: 175). However, such a redefinition of the term seems to go against researchers who, in the name of 'World Christianity' and a certain sense of theological normativity, do pursue Christian missions and ecumenical unity (e.g. Chung 2010; Werner et al. 2010; Robert 2013), but also pose questions to Phan's assumption that "[one Christian] faith which is expressed and practiced in myriad ways and in different locations altogether constitutes what we called world Christianity" (Phan 2012: 175).

I argue that the modifier 'world' does not automatically stand for an allinclusive body of Christianities worldwide; rather, we need to unpack the manifold meanings and conceptualisations of the modifier in order to test its applicability as a methodological tool for studying Christians and Christian communities worldwide. The notion of 'World Christianity' needs to be placed in broader intellectual discourses that emphasise world-mindedness by using the modifier 'world' in articulating modes of research such as world history, world philosophy, and world literature. The term also deserves attention in light of the emergence of terms that derive most of their meaning from the modifier 'world', such as 'world wars', 'world bank', 'world heritage', 'world fashion', or 'world community'. Booming research and publishing on 'World Christianity' coincides with recent trends of worlding in other fields of study. With regard to such interdisciplinary worldings, my aim is to show how arguments about conceptualisations of world literature, world philosophy, and world history could assist us in further developing 'World Christianity' as a methodological approach.

Similarly to attempts that conceive of 'World Christianity' as a field of study or a phenomenon, there has been a growing body of literature applying the 
same approach to world literature, world philosophy, and world history. To mention but a few examples, titles such as How to Read World Literature (Damrosch 2017), The Oxford Handbook of World Philosophy (Garfield and Edelglass 2011), or World History. An Introduction (Vanhaute 2013) reference projects similar to those on World Christianity. Of course, they are right in claiming that the issue of power relations and inequalities is integral to addressing worlded literature, history, philosophy, or Christianity, because these worlded 'entities' usually do not circulate freely across socio-political (and academic) borders; however, they seem to frame inclusivity across all times and places, and operate either within a west versus the rest or Eurocentric framework, or a unbalanced focus on postcolonial discourses. For example, in the Introduction to The Oxford Handbook of World Philosophy (2011), William Edelglass and Jay L. Garfield explain the omission of "Western philosophy" from the handbook as follows: "We have taken it as obvious that most contemporary academic philosophers in the world are well acquainted with the European tradition, and so take 'world philosophy' to be like 'world music' - everything but European. There will, we hope, come a time when the European case is so unmarked that this would be an inexcusable omission" (2011: 6). This argument seems to contradict another observation they make in their introduction, namely that there is a widespread tendency to believe that one's culture, and the philosophical tradition emerging from it, might be unique and superior to others (2011: 3).

As indicated in the introduction, this chapter seeks to identify arguments that address the conceptual legitimacy of worlding certain notions. Therefore, I shall not discuss the conceptualisation of worldings as fields of study or disciplines, or the methods through which these are transformed into compendia; nor do I discuss globalisation and cultural turn theories and their effect on researching Christians and Christian communities. I fully agree with Emily Apter when she writes that "I have been left uneasy in the face of the entrepreneurial, bulimic drive to anthologise and curricularise the world's cultural resources as evinced in projects sponsored by some proponents of World Literature" (Apter 2013: 2), and I would add 'W[orld] Christianity' as well, but I humbly and respectfully admit that those efforts should not be so easily dismissed. For the purposes of this chapter, I chose another path in the form of three excursions, the first of which is into world literature.

\section{World Literature}

Similarly to unsettled discourses on the booming business of 'World Christianity', unsettled discourses on world literature and its marketisation 
are also thriving (Alon 2016). I have already mentioned Phan's observation that 'World Christianity' in its current usage usually refers to an all-inclusive compendium of what has been identified, or has identified itself and identifies as Christian over the last two millennia. However, in all its inclusivity, this worlding of Christianity seems problematic, and its problematic nature can best be illustrated by looking at lessons learned from conceptualisations of world literature.

Similarly to investigations of the notion of 'World Christianity', several scholars have searched for a genealogy of the notion of world literature. While there is a more or less general consensus that discourses on present worldings of literature cannot avoid Johann Wolfgang Goethe's concept of Weltliteratur, there is less consensus about the actual meaning of the Goethean concept, which leads to conflicting readings of Goethe, and hazy connotations when it comes to the concept of world literature. The widely quoted Goethean statement from 1827 about the emergence of an "epoch of world literature" 6 can be and has been read in different ways. For example, Jérôme David (2013) identified four competing genealogies (methodological, critical, pedagogical, and philological), which are related but not necessarily originating from the Goethean concept, and operating with distinct agendas. The methodological genealogy resonates with the idea of 'World Christianity' scholars who call for the inclusion of neglected, silenced, or forgotten components of an all-encompassing Christianity. Such a methodological genealogy "designates everything our interpretative habits do not incorporate" (David 2013: 23), and formulates the power relations and dynamics inherent to knowledge construction in terms of justice. The critical genealogy initiates discourses on 'national versus transnational', but does not necessarily dismiss that dichotomy. For example, for Goethe, engagement with the literature of 'foreign nations' could also imply the improvement of one's own Germanness. The critical genealogy also implies a judgmental attitude towards literature that does not qualify as such, and points to the issue of the commerciality of written/produced texts. Goethe seemed to be rather critical of cheap but well-selling literature, yet as David (2013) illustrates with an anecdote, it was precisely the cheap and widely

6 "We Germans are very likely to fall too easily into this pedantic conceit, when we do not look beyond the narrow circle that surrounds us. I therefore like to look about me in foreign nations, and advise everyone to do the same. National literature is now a rather unmeaning term; the epoch of world literature is at hand, and everyone must strive to hasten its approach" (Goethe, Sämtliche Werke ['All Works'], 12/224 f.). 
circulating translations of two Chinese novels that led to Goethe's revelation on world literature. ${ }^{7}$

The genealogies described above bring to mind discourses on ranking theologies, such as the 'theologies from below versus theologies from above', or 'popular theology versus academic theology', and the translation and translatability of these terms. The latter leads to the third genealogy in David's work, the pedagogical genealogy, which may serve different ideologies to develop their educational system. Finally, the fourth or the philological genealogy is preoccupied with issues of meaning and language, and thus, translation and translatability. This genealogy comes closest to the question of sources and their usage in theological and missiological research, and programmatically culminates in the advocacy of going beyond the concept of 'nation' as the sole analytic unit for research. David's philological genealogy begins with Goethe, and discusses such established scholars as Erich Auerbach in order to demonstrate that philology is more than just texts from the past, since there is human agency behind 'creating' humanity (from a theological point of view, it is human agency and their interaction with God), which means that both texts and "forms of lives" (Lebensformen) in their verbal and non-verbal (material) demonstrations belong to it. Insights from the philological genealogy resonate with the principle of a World Christianity approach based on the understanding of a shared humanity. Scholars looking at the Goethean concept from different knowledge traditions thus arrive at similar observations.

In a paper about discourses on world literature, Shanghai-based scholar Wei Maoping (2012), who was responsible for the first complete translation of Goethe's work into Mandarin, argued that Goethe's coining of the term Weltliteratur is strongly connected with the worlded socio-political and economical terminology of Goethe's time, such as 'world trade' (Welthandel) and 'world economy' (Weltwirtschaft). In Goethe's time, those notions signified an increasing and accelerated way of connecting 'citizens' through trade and economy with different people across the world, yet this connectivity, similarly to contemporary assessments of globalisation processes, was not uncritically received. Wei argued that dictionary definitions of world literature, whether defining it in terms of quantity as literature across all times and places, or in terms of quality as canons of literature that qualify certain works as world

7 The texts the anecdote refers to were most probably two love stories (Haoqiu zhuan ['The Pleasing History'] and Yu Jiao Li ['Jade Charming Pear'], authorship unknown). Both stories are highly didactic, and as $\mathrm{Ma}$ (2012) observes, both establish a link between public and private virtue, an issue with considerable relevance for self-cultivation. 
literature while excluding others, miss the original meaning of Goethe's concept, which was a programmatic idea aimed at transforming society, even global society, by practicing world literature as encountering the other who helps the self in becoming more and more human (Wei 2012). Such a reading combines the clearly separated genealogical agendas of David by underlining the normativity of conceptualisations of world literature. More than that, world literature in this sense is not only a normative activity, but also a tool for ethical and political transformation (Cheah 2008), which aims to realize a global community through the consciousness of our shared humanity.

The idea of a shared humanity brings us to the idea of cosmopolitanism or "all under heaven" (tian xia), which since Socrates (to take a Greek classic) or Zhou (to reference Chinese collective memory) has operated on the argument that self-cultivation or the improvement of the self is only achievable through encounters with people who think, act, and behave differently from us (here, again, the issue of alterity rears its head). Meanwhile, according to Pheng Cheah, cosmopolitanism is not one of "perceptual experience but of the imagination. World literature is an important aspect of cosmopolitanism because it is a type of world-making activity that enables us to imagine the world" (Cheah 2008: 26). Yet at this stage, we must note that when made into a world-making project, world literature needs to be critically revisited and tested so cosmopolitanism or the idea of "all under heaven" as "a moral universalism" does not degenerate into imperial globalism: "The continuous shift of cosmopolitan ideas towards empire is one of the dominant motifs of modernity" (Vladimir Biti quoting Costas Douzinas 2016: 155). From this, Biti draws the following conclusion:

Maintenance of its democratic character, not its celebrated "dialogue of equals" but its neglected constitutive disagreement between agencies and enablers has to be consistently practiced. What this unflagging practice is intended to foreground is that world literature is not so much a generous project of reconciling the divided parties, as it is regularly presented to be, but rather a compensatory project designed to come to terms with the underlying trauma of division. While systematically healing one traumatic experience, however, it cannot but inflict others.

Biti 2016: 163

It is precisely the reproduction of old and harmful patterns of practicing intercultural exchange based on the principle of translatability that Apter argues against in her Against World Literature (2013) when she says that we need to be aware of power relations when it comes to using language and translation for 
mediating meaning, and to the ideologies that facilitate such mediation (such as the ideology of expansion).

In making a connection between World Christianity discourses and world literature discourses, the role of languages in stimulating and facilitating encounters among different agents remains crucial and relevant. Consider the case of the Manifeste pour une "littérature-monde" en français ['Manifesto for a "world literature" in French'], which was published in the newspaper Le Monde ['The World'] on 15 March in 2007, ${ }^{8}$ and signed by forty-four writers who advocated for a shift in terminology, for replacing the term francophone with "literature composed in French," and against such binary categories as the centre and the margin, the coloniser and the colonised. Reflecting on this manifesto, Subha Xavier concluded that it is "an opportunity for scholars of French literature to think beyond colonial and postcolonial rubrics, to the realities of migration and globalization, cosmopolitanism and multilingualism" (Xavier 2010: 64). According to Adele Parker, "the unsettled power relationship between Eastern and Western Europe is at the heart of the Manifesto, and it signals an increasing resistance against Paris being the centre of literature and thus creating peripheries around itself" (Parker 2013: 193). Conceiving of world literature as an interpretative tool of global living together also considers the role of the global movement of people, their encounters with each other, and how these encounters change their imaginaries of the world. In her paper, Xavier looks at the littérature migrante as emerging in the last thirty years (Xavier 2016), but her arguments could be used for studying world-making texts from all ages.

My short excursion into discourses on conceptualising world literature reveals several methodological issues. For one, it makes clear that literature scholars (who critically address the worlding of literature) do not tend to speak of world literature as a discipline or phenomenon, and that Goethe's epoch of Weltliteratur is rarely understood in terms of phenomenology. Rather, scholars try to identify the methodological aspects of using the term in fostering academic discourses on practicing literature studies in worldwide connectivities, and they do so in a programmatic and normative way. The issue of normativity (with regard to cohabitation), the issue of communication addressing the usage of language and its translatability, and the power dynamics inherent in normativity and communication are some of those methodological aspects. In fact, neither normativity nor translatability can be addressed without introducing two more concepts: recognition and comparability, which both

8 The text is available at the following link: http://www.lemonde.fr/livres/article/2007/o3/15/ des-ecrivains-plaident-pour-un-roman-en-francais-ouvert-sur-le-monde_883572_326o.html, date of access: 13 June, 2018. 
indicate that all agents involved in worlding discourses (researchers and researched ones, to propose a new dichotomy) reveal different aspects of, and construct identities through, practices and interactions. I now turn to these concepts in my next excursion into the concept of world philosophy.

\section{World Philosophy}

In a paper on the concept of world philosophy, Singapore-based philosopher Saranindranath Tagore (2017) argued that the concept functioned as "the pivot on which comparative philosophy turns" (Tagore 2017: 531). It is this postulation, and the insights I had gained from different conceptualisations of world literature, that made me look deeper into his arguments. The issue of comparability is crucial for the matrix of interconnectivity, unity, diversity, and locality, which formed the basis of my previous discussions of World Christianity as an approach. In his arguments, Tagore enters into dialogue with sceptical approaches towards world philosophy: by using the examples of modernist Edmund Husserl and post-modernist Richard Rorty, he demonstrates the replication of the same exclusionist position. Whereas Husserl argued against the broadening of the Eurocentric way of doing philosophy based on the claim that any philosophical tradition that refuses to make theoria (implying no consideration of praxis) its key concept cannot be called philosophy, Rorty delegitimised comparison because "acts of comparison across philosophical cultures imposed one's favoured conceptual scheme to generate similarity which as a matter of fact is absent" (Tagore 2017: 533). From these examples, Tagore concludes that the Greek grand narrative of Husserl operates on the same logic of excluding alterity as Rorty's arguments on fragmentation. Similar sceptical discourses are observable within discourses on alterity and Christianity, which create the false impression of a contradiction between the one (grand narrative) and the many (stories, fragments), when in fact these apply the same patterns of excluding alterity.

In order to transcend the sceptical, and in Tagore's reading, violent and exclusionist positions of Husserl and Rorty, Tagore proposes a Kantian (another modernist) approach based on the a priori proposition of possibility for conditioning comparison and conceptualising world philosophy. Through Kant, Tagore arrives at Goethe's Weltliteratur, and postulates that recognition lies at the heart of Goethe's concept: in other words, the act of recognising a shared humanity while reading a translated Chinese text. For Tagore, the concept of recognition recalls the normative praxis of philosophy. He agrees with Charles Taylor's Politics of Recognition (1994) when he claims that the possibility of 
comparison lies in recognising alterity, which leads to a world philosophy approach through which different socio-historically situated traditions can connect with each other, communicate, and exchange ideas: "The act of recognition alone can introduce 'world' to the understanding of a disciplinary tradition, literary or otherwise" (Tagore 2017:538). The act of recognition in worlding proposes a corrective approach to any theological- missiological understanding of alterity that operates on a Christian versus non-Christian binary.

I take Tagore's arguments as components for constructing a world philosophy approach (although he does not use the term approach), which implies a "hermeneutically malleable condition open to acts of interpretation" (Tagore 2017: 540), through which comparability and non-comparability can be addressed and thematised. "Only this act of recognition can allow the force of the world to open up to isolated interiority of the fragment" (Tagore 2017:540), where "interiority" implies the possibility of superiority. What Tagore does not emphasise is that recognition for both Goethe and Taylor is inseparable from the question of identity, or the question of agency. I shall illustrate this with the following example.

In 2005, on the initiative of Turkey (in reductionist terms, a personified and "non-Christian nation state"), the United Nations Educational, Scientific, and Cultural Organization (UNESCO) introduced World Philosophy Day, to be celebrated on the third Thursday in November each year. The Resolution adopted by the General Conference in October 2005 states that "philosophy is a discipline that encourages critical and independent thought, and is capable of working towards a better understanding of the world and promoting tolerance and peace," and adds with conviction that "world philosophy day would win recognition for and give strong impetus to philosophy and, in particular, to the teaching of philosophy in the world" (UNESCO 2006: 15). This underscores the relevance of Goethean Weltliteratur as a world-making activity project, and comes close to Karl Jasper's Weltphilosophie, understood through different hermeneutical lenses (Saner 1988; Teoharova 2005; Murata-Soraci 2010; Hügli 2012), which implies an intentional intellectual praxis of peace-searching and peace-building by identifying a shared humanity and an encompassing communication. It also claims that the understanding of the discipline of philosophy offers a method of transforming the self, training others, and transforming societies (Hadot 1995: 107).

A UNESCO Strategy for Philosophy, which was written in 2005 by Senegal-born political scientist Pierre Sané, strategically invites all philosophers of the world to promote "dialogue and philosophical analysis of contemporary questions," to encourage "teaching of philosophy" for the sake of free and well-informed thought, and to promote and disseminate "philosophical 
knowledge in order to make sure that philosophy is accessible to all" (UNESCO 2006:4). This example illustrates that it is not enough to construct a genealogy of worlded notions, and thus confirm that they have repeatedly been rebooted; it is also important to look at by whom, how, and why such worldings have happened and continue to happen. Looking at the UNESCO examples through Tagore's arguments, recognition needs to be considered, because recognition has always been a question of identity spelled out in terms of representation and presentation, of the commensurability of philosophical traditions, and of the creation of a shared language through which communication can take place. However, such an epistemological stance on alterity is already a theological, philosophical, and ideological position that starts with (our) a belief in a shared humanity.

The UNEsCo examples described above suggest that we (academics working with the concept of 'World Christianity') should revisit programmatic discourses on worlding Christianity. To my mind, worldings in literature and philosophy underscore the preoccupation of a 'World Christianity' approach with sources and agency. These excursions make clear that worldings imply a committed hermeneutics of written texts, and an exploration of being (the ultimate question of identity and relationality) as understood through lived experiences expressed verbally and non-verbally. As long as there is an outspoken desire for recognising philosophical (especially in terms of transcendental philosophy) and religious traditions (Phan 2012), while commensurability is considered (Cabrita, Maxwell and Wild-Wood 2017), and there is a commitment to developing new terminologies that address difference and similarity (Tan and Tran 2016), these need to be tackled in an ongoing conversation about recognition and identity through presentation and representation. With reference to these latter notions, I shall now start my third excursion into worlding history.

During the last few decades, as has been the case with world literature and world philosophy, preoccupation with world history in academia has intensified as well, not only in publishing, but also in curriculum development, which treats world history as a subdiscipline. While the jury is still out on whether world history and global history mean the same thing, in this section I shall discuss scholars who use these terms interchangeably. ${ }^{9}$

9 Similar discussions on the distinct or interchangeable meaning of the modifiers 'global' and 'world' for Christianity have also emerged in World Christianity discourses; see the discussion 
The emergence of world history as a discipline is dated to 1982 , when the World History Association (WHA) was established to propagate "[a] shift in higher and secondary education away from a sole emphasis on national and regional histories toward broader cross-cultural, comparative, and global approaches." ${ }^{10}$ The wHA may be a North American enterprise, but there are also worldwide collaborations of scholars practising world history, such as the team built around World History Sources:

[The wHs lays] an emphasis on comparative issues rather than civilizations in isolation; a focus on contacts among different societies and the economic, social, and cultural consequences of those contacts; and an attentiveness to "global" forces that transcend individual societies or even societies in mutual contact - forces such as technology diffusion, migration, disease transmission, extension and realignments of trade routes, or missionary outreach. World History Sources also benefits tremendously from recent advances in our understanding of how historical learning takes place, building on strategies designed to improve historical learning and history teaching..11

The statement above brings to mind an UNESCO project, which was launched in the era of World War II with the aim of peace-making, as well as underlining the ideas of interconnectedness, interdependence, international unity, and modes of representation (Duedahl 2011). These arguments resemble the world-making normativity I discussed in the previous sections. While discourses on 'World Christianity' do not necessarily point to methodological developments in world/global history research, they do formulate strikingly similar arguments. Whether it is 'Transcontinental Links, Enlarged Maps, and Polycentric Structures in the History of World Christianity' (Koschorke 2016), The Cross Cultural Process in Christian History (Walls 2002), Christian Histories, Christian Traditioning: Rendering Accounts (Irvin 1998), "Twentieth-century World Christianity" (Stanley 2004), Christian Mission. How Christianity Became a World Religion (Robert 2009), History of the World Christian Movement (Irvin

between Philip Jenkins and Lamin Sanneh. In the preface of the revised edition of The Next Christendom (2007), Jenkins addressed his terminology in relation to Sanneh, who made a distinction between the two terms in his book, Whose Religion is Christianity: The Gospel beyond the West (2003). Sanneh replied to Jenkins in Disciples of All Nations. Pillars of World Christianity (2008). Their arguments about making a distinction between 'global' and 'world' Christianity seem to rely on a static understanding of Christian identities.

10 Source: https://www.thewha.org/about/, date of access: 13 June 2018.

11 Source: http://chnm.gmu.edu/worldhistorysources/whmabout.html, date of access: 13 June 2018. 
and Sunquist 2001, 2012), or "World Christianities. Transcontinental connection" (Phan 2016), they seem to live up to the "urgency of the task:"

[To expand] the "cartography" of church history, that is, to study the geographical areas hitherto neglected in traditional church history, is made urgent by the recent momentous demographic shift of the Christian population from the Global North to the Global South, with the projected presence of four-fifths of Christians living in Asia, Africa, and Latin America by 2050. [...] By enlarging the "topography" of traditional church history is meant first changing its methodological approach. Instead of centering the narrative on the achievements of hierarchical leaders (often male and white) and Western missionaries, attention should be turned to the contributions of the people who have been marginalized in church history such as lay men and women, religious sisters, the poor, the tribals, and those accused of heresy, schism and syncretism.

Phan partly referencing Justo González 2012: 178

It is mainly in the new historiography described above that the four keywords I have chosen for developing World Christianity as an approach can be found: unity, diversity, connectivity, and locality. These keywords belong to a larger vocabulary through which connections and comparisons are explored "with sensitivity for the more flexible and fluid dimensions of historical change" (Conrad 2016: 64). Scholars who conceive of world/global history as an approach, such as Sebastian Conrad, emphasise that connectivity and its related vocabulary do not convincingly guarantee originality in research: "Connections need to be embedded in processes of structural transformation, and this on a global scale" (Conrad 2016: 64-65). This argument resonates with the findings of the previous two excursions, namely that worldings usually have an ideological basis.

When we attempt to develop a genealogy of the concept of 'world history' using Hegel's Weltgeschichte, which is a philosophy (even theology) of the history of the world, it becomes clear that it is a normative ideology based on determinism and providence, which sees world history as a staged history that moves towards the realisation of human freedom (Hodgson 2012). ${ }^{12}$ Change (Veränderung), and the creation of new life (neues Leben) and reason (Vernunft) are the interpretative categories for the universal. But then, ideologies usually are controversial. For example, Ranajit Guha (2002) offers a postcolonial critical analysis of Hegel's concept of world history, and proposes conceptualising world history through methods that research narrativity. Building on Tagore's

12 For a critical analysis of Hegel's world history, see Guha (2016). 
critique of historiography, he envisions world history as "a narrative concerned with the everyday world" (Guha 2002: 74). Addressing the historicity of everyday life not only implies making room for the pasts of the "peoples without history," but also addressing the history of everyday life itself (such as materiality). Only then, as Guha demonstrates through an examination of Tagore's critique of historiography, can we recapture a more fully human past of "experience and wonder."

The mirroring of arguments described above brings us back to Tagore's conclusion on paralleling Husserl and Rorty, who both raised questions about alterity, representation, and the possibility of recognition, despite coming from two different traditions. To what extent could a world/global history approach provide tools for creating the possibility of recognition? In order to answer this question, I turn once more to Conrad (2016), whose conceptualisation of 'worlding' within his own field shows similarities with what Frederiks and I do when we discuss 'World Christianity' either for religious studies or theology and missiology.

When elaborating on global history as an approach, Conrad not only prescribes a conscious search for processes of structural transformation, but he systematically describes seven methodological choices through which one can apply such an approach. The first methodological choice is that beyond providing a macro-perspective, a world history approach also pays attention to micro- and meso-perspectives, which clearly ties into the issue of representation, and brings to mind the methodological choices of the anthropology of Christianity (e.g. Hann 2014). The second choice is that a world history approach works with an open understanding of space; for example, it implies that nation states are not naturally prescribed research units. The third choice is that a world history approach is aware of relationality when it comes to historiography. The fourth choice, connected to the earlier choices, is that a world history approach operates through the logic of the 'spatial turn', implying that connections between localities through migration, traveling, and material objects are of greater interest than notions such as development and time lag. This is a clear rejection of any understanding of teleological history based on the normativity of one narrative (or any narrative for that matter). This brings us to the fifth choice, which is that a world history approach sees synchronicity as crucial for research, implying the rejection of operating through metaphors such as centres and peripheries. The sixth choice is the issue of the self-reflexivity of the researcher, mainly practiced in the form of a critique of Eurocentrism. Finally, the seventh methodological choice Conrad identifies is integration, which brings him back to the argument that prioritizing the study of connectivity for a world history approach is not enough, 
because the significance of connections (or the lack of them) depends on the components of the given circumstances: "Exchange in other words, may be a surface phenomenon that gives evidence of the basic structural transformations that made the exchange possible in the first place. Effective global history needs to remain aware of the systemic dimension of the past, and of the structured character of social change" (Conrad 2016: 70). This argument resonates with the point Frederiks and I repeatedly make in this volume, namely that a World Christianity approach, similarly to a world history approach, needs to be aware of power structures, and in light of those power structures, it needs to address the issue of agency: "Failure to note power structures confers agency on everyone who is involved in exchange and interactions, and by celebrating mobility runs the danger of ignoring the structures that control it" (Conrad 2016: 71). In conclusion, for Conrad, a world history approach that tackles the issues of comparison and connections has to focus on "large forms of structured transformation and integration" (Conrad 2016: 72).

In any case, a world history approach as proposed by Conrad seems to be less preoccupied with the topography and cartography of the world ('World Christianity') and more preoccupied with going "beyond the dichotomy of internal and external altogether" (Conrad 2016: 89). It is about self-reflexivity, relationality (connectivity), and the acknowledgement that "causal relevance of factors that do not lie within the purview of individuals, nations, and civilisations" are relevant (Conrad 2016: 89).

Back to the Matrix of Locality, Unity, Diversity, and Connectivity

In the introduction of this chapter, I proposed three brief excursions into world literature, world philosophy, and world history respectively, with the aim of further developing a World Christianity approach for theological and missiological research, which I initially framed through the notions of locality, unity, diversity, and connectivity. These excursions opened up new vistas through which a World Christianity approach could be further developed.

In light of the arguments on worldings, and especially with Conrad's world history approach proposal freshly on our minds, I shall now return to the question of history in world Christianity discourses, and examine to what extent the above outlined methodological choices have relevance there. Conrad, in a way summarizing the arguments presented in worldings of literature and philosophy, shows that the unity, diversity, locality, and connectivity formula implies an inherent relationality, self-reflectivity, and the exploration of alternative spatialities (Conrad 2016: 9o). In my opinion, 'World Christianity' 
as an approach should be guided by questions such as to what extent 'World Christianity' scholars operate with an open concept of locality when it comes to research design; to what extent a practice of case studies method can help in researching relationality; how is synchronicity being researched within the framework of 'World Christianity', and above all, what is the relationship between theological standpoints and addressing power structures?

Based on the limited material discussed in this chapter, I make the following observations:

Neutrality in worldings is not an option. World literature, world philosophy, and world history work with scopes and set methodological agendas. The recognition of a shared humanity seems to be one of the starting points based on which worlding approaches operate. While acknowledging the legitimacy of researching Christians and Christian communities worldwide (a position I repeatedly articulate), researching them does not mean a limited and exclusive attention to Christians only (Wild-Wood 2017: 324). Studying the issues of unity, diversity, and locality is always about relations, the connections of Christians and Christian communities with larger social settings, and avoiding internalist paradigms. Such a research focus does not recreate the old Christian and non-Christian dichotomy, but looks at cohabitation or living together from the perspective of a shared humanity, and at boundaries set by complex power relations. For example, a 'World Christianity' approach should be critical of denominational labels, and seek to move beyond studying Christianity in the framework of the nation state and national institutions (i.e. churches). It is within our shared humanity that diversification and unity (among Christians, and beyond) become relevant issues and can be discussed. At the core of this nonneutral worlding and this 'World Christianity' approach, the following issues remain crucial: what/who is a Christian; who identifies and who is being identified as such; who and how are Christian communities; what are their beliefs, and what do they teach? The non-neutrality of worlding, then, is considered both at the level of data and modes of analysis (the complicated relationship between researcher and human agency involved in research). In other words, a World Christianity approach always keeps in mind the non-neutrality of the researcher.

Transformation is a shared agenda. All three excursions revealed that worldings as research approaches have public and political functions, and they call for a change in research practice in literature, philosophy, and history. Worlding Christianity for an approach could subscribe to this agenda, especially through an understanding of the theological praxis of loving God and loving one's fellow human beings, and with the public and political aspiration of contributing to peaceful cohabitation worldwide. The idea of transformation encompasses 
every sector and corner of the planet, and reveals that it is not only theology that is preoccupied with peace-building and stewardship for the planet. Theology and missiology are also preoccupied with the idea of transformation, in the sense of a world-making activity that is always based on normativity. Yet, to put transformation on the agenda of a World Christianity approach means a balanced preoccupation with changing, changed, and unchangeable components of worldwide processes. Referring back to Conrad, one should not be led astray by voices that legitimise speaking about transformation through a narrow understanding of change as experienced through mobility, flow, and migration. A World Christianity approach is interested in transformation related to knowledge construction.

Research is recognition, representation, and revision. By discussing worldings in different disciplines, with the aim of further reflecting on what a World Christianity approach might mean for studying the complex entanglements of Christians and Christian communities worldwide, I aimed to highlight the multi-layered nature of such research. A new historiography as envisioned under the key term 'World Christianity' by the Munich School and other scholars-such as Andrew Walls, Brian Stanley, Emma Wild-Wood, and Dana Robert—, seeks to find sources and voices that are neglected, unheard, or marginalised by a Eurocentric construction of historiography. Yet recognition and representation also need to be addressed in relation to the person of the researcher, who is another active agent of knowledge construction. When dealing with the issue of alterity, and the tension between sameness and difference, the researcher needs to tackle the different levels and degrees of recognition and representation. Therefore, who recognises and represents the researcher is a legitimate methodological question. To put it differently, who is worlding what, and whose worldings are recognised and/or revised by whom? The issue of the researcher's autonomy is one of complex power relations through which academic institutions are created, and in those power relations, knowledge might become a commodity being produced and sold according to certain types of entrepreneurial academics. The hegemony of English as an academic medium in working with 'World Christianity' (in whatever forms), and the ways in which universities and research institutions/centres operate through English as a lingua franca also have serious consequences for recognising both the research and the researcher. On the one hand, we need a shared language in order to communicate; on the other hand, communicating in English as a second, third, or even fourth language might mean a limited way of expressing our insights and knowledge.

Communication and the commensurability of languages are not selfevident. When Phan (2012) describes the implication of 'World Christianity' 
for religious studies, history, and theology, he indirectly addresses the issue of communication. Both the excursion on world literature and world philosophy illustrate that it is again the act of recognition from which any act of communication can begin. The aim is not simply the broadening of the theological vocabulary and conceptual toolbox under the motto 'including all Christians from all ages and places with their languages and messages'. A World Christianity approach is preoccupied with languages, translatability, and untranslatability for a theological and missiological praxis, which aims at peaceful cohabitation in the present, and looks at complex modes of cohabitation in the past. My excursions demonstrated that communication and connection are usually interpreted as occurring between distant parties, while a World Christianity approach proposes that we tackle the issue of communication on a smaller scale as well. The commensurability of languages is not necessarily a transnational issue: it needs to be considered within a neighbourhood, a town, or within a Christian community. The re-envisioning of systematic theology happened and continues to happen when theologians and missiologists study communication, and communicate with others, and not just those whose languages they happen to speak. Language and communication for a World Christianity approach should never be about the translatability of the Message, which presupposes one single Christian language that spoken languages must adapt to, but the other way around: it is about the communicability of faith confessed through relations based on recognition. A World Christianity approach takes as its starting point the polidoxy of Christians and Christian communities worldwide (Keller and Schneider 2011), looks at them through different scales (research units), and seeks to study their interconnectedness. Due to the different grammars and semantics of spoken languages, these endeavours must remain conscious of the technicalities of these languages.

\section{In Lieu of a Conclusion: Further on the Path of Knowledge Construction}

In the introduction of this chapter, I expressed my intention of elaborating on 'World Christianity' as an approach, paying close attention to the ways in which discourses on 'World Christianity' relate to the issue of knowledge construction. Knowledge construction is directly linked with understanding and undertaking research, and translating it into teaching/education. Focusing on the notion of 'worlding', I looked at how 'world' as a modifier has been used in the humanities. I presented the insights I had gained from worlding literature, philosophy, and history, and demonstrated that such worldings point to 
a myriad of questions about basic relationalities (I/we/it and you/them), with the researcher also being a part of those relationalities. My excursions showed that tackling questions about alterity creates space for, and even requires us to acknowledge normativity, because normativity is already mirrored in the way researchers design their research. I discussed Conrad's call for going beyond internalist paradigms, which for theologians might imply moving beyond the limiting dichotomy of Christian and non-Christian that often stifles the creativity of research processes. The concept of normativity and its relevance for a World Christianity approach needs to be given more attention in future publications. I pointed out that much of the worlding in literature, philosophy, and history acknowledges a shared humanity (think of the concept of 'humanities' in this light), not only as the field, but also as the task of academic enterprise. Yet both from a philosophical and a theological perspective, we still need to find answers to the question, to what extent is a belief in a shared humanity the only basis for reflective and responsible academic work? In such worlding approaches, normativity, recognition, comparability, and communication become methodological steps of invention and creation.

In light of the arguments presented in this paper, I conclude that conceiving of 'World Christianity' as an approach starts with the recognition that knowledge construction is always purposeful action, meaning that it is both reflective and intentional. Looking at the multi-layered discourses on 'World Christianity', we could say that both reflexivity and intentionality have been addressed, yet they need to be systematically and methodologically deepened. For theologians and missiologists practicing World Christianity as an approach, there is still a long way to go. However, it is important to realize that we are not alone in this endeavour, because we have the resources and insights of the disciplinary other, who can accompany us on this journey.

\section{Bibliography}

Alon, Shir (2016). 'The Becoming-Literature of the World. Pheng Cheah's Case for World Literature.' https://lareviewofbooks.org/article/becoming-literature-world -pheng-cheahscase-world-literature/ accessed 12 January 2018.

Altamirano, Marco (2014). 'Three Concepts for Crossing the Nature-Artifice Divide. Technology, Milieu, and Machine.' Foucault Studies 17: 17-35.

Apter, Emily (2013). Against World Literature. On the Politics of Untranslatability. London/New York: Verso.

Barreto, Raimundo C., et al. (2017). World Christianity as public religion = Cristianismo mundial como religião pública. Vitória, ES: Editoria UNIDA. 
Biti, Vladimir (2016). Tracing Global Democracy. Literature, Theory, and the Politics of Trauma. Berlin: de Gruyter.

Cheah, Pheng (2008). 'What is a World? On World Literature as World-Making Activity.' Daedalus 137,3: 26-38.

Chung, Paul S. (2010). Public Theology in an Age of World Christianity. God's Mission as Word-Event. London: Palgrave.

Conrad, Sebastian (2016). What is Global History? Princeton: Princeton University Press.

Damrosch, David (2017). How to Read World Literature. Hoboken: Wiley-Blackwell.

Danielson, Robert A. and Linda F. Whitmer, eds (2016). Teaching Christian Mission in an Age of World Christianity. The 2016 proceedings of The Association of Professors of Missions. St. Paul, Minnesota, June 16-17, 2016. Wilmore, KY: First Fruits Press.

David, Jérôme (2013). 'The Four Genealogies of “World Literature”.' (transl. by Mary Claypool). In Joachim Küpper, ed., Approaches to World Literature. Berlin: Akademie Verlag: 13-26.

Duedahl, Poul (2011). 'Selling Mankind. UNESCO and the Invention of Global History, 1945-1976.' Journal of World History 22,1: 101-133.

Garfield, Jay L. and William Edelglass (2011). The Oxford Handbook of World Philosophy. Oxford: Oxford University Press.

Goethe, Johann Wolfgang (1986-1999). Sämtliche Werke. Edited by Friedmar Apel, Hendrik Birus et al. Frankfurt am Main: Deutscher Klassiker Verlag.

Guha, Ranajit (2002). History at the Limit of World-History. New York: Columbia University Press.

Gruber, Judith (2013). Theologie nach dem Cultural Turn. Interkulturalität als Theologische Ressource. Stuttgart: Kohlhammer.

Gruber, Judith (2018). Intercultural Theology. Exploring World Christianity after the Cultural Turn. Göttingen: Vandenhoeck \& Ruprecht.

Hadot, Pierre (1995). Philosophy as a Way of Life, ed. Arnold Davidson and trans. Michael Chase. Oxford: Blackwell.

Hann, Chris. (2014). 'The Heart of the Matter. Christianity, Materiality, and Modernity.' Current Anthropology 55,10: 182-192.

Hodgson, Peter C. (2012). Shapes of Freedom. Hegel's Philosophy of World History in Theological Perspective. Oxford: Oxford University Press.

Hügli, Anton (2012). 'World Philosophy. On Philosophers Making Peace.' In Helmut Wautischer, Alan M. Olson and Gregory J. Walters, eds. Philosophical Faith and the Future of Humanity. Dordrecht/London/New York: Springer: $335-345$.

Irvin, Dale T. (1998). Christian Histories, Christian Traditioning. Rendering Accounts. Maryknoll: Orbis Books.

Irvin, Dale T. (2016). 'What is World Christianity?' In Jonathan Y. Tan and Anh Q. Tran, eds. World Christianity. Perspectives and Insights. Maryknoll: Orbis Books: $3^{-26}$. 
Irvin, Dale T. and Scott W. Sunquist (2001). History of the World Christian Movement. Vol. 1: Earliest Christianity to 1453. Edinburgh: T\&T Clark.

Irvin, Dale T. (2012). History of the World Christian Movement. Vol. 2: Modern Christianity from 1454-18oo. Maryknoll: Orbis Books.

Jenkins, Philip (2007 revised edition). The Next Christendom. The Coming of Global Christianity. Oxford: Oxford University Press.

Keller, Catharine and Laurel C. Schneider (2011). Polidoxy. Theology of Multiplicity in Relation. New York: Routledge.

Koschorke, Klaus (2016). 'Transcontinental Links, Enlarged Maps, and Polycentric Structures in the History of World Christianity.' The Journal of World Christianity 6,1: 4-27.

Ma, Ning. (2012). “'A Strong Resemblance”. Samuel Richardson, Chinese Talent-Beauty Novels, and the Secret Origins of the "World Literature".' In Rachana Sachdev and Qinjun Li, eds. Encountering China. Early Modern European Responses. Lewisburg: Bucknell University Press: 103-126.

Murata-Soraci, Kymyio (2010). 'Tracing Confucius in Jaspers' Weltphilosophie.' Existenz 5,1: 16-22.

Nagy, Dorottya (2017). 'World Christianity as a Theological Approach. A Reflection on Central and Eastern Europe.' In Joel Cabrita, David Maxwell and Emma Wild-Wood, eds. Relocating World Christianity. Interdisciplinary Studies in Universal and Local Expressions of the Christian Faith. Leiden: Brill: 143-161.

Nyeko, Kizito Emmanuel and Ngui Kwang Sing. (2015). 'Academic Entrepreneurs and Entrepreneurial Academics. Are They the Same.' International Journal of Social Science and Humanity 5,12: 1050-1055.

Ong, Walter (1969). 'World as View and World as Event.' American Anthropologist 71: 634-647.

Parker, Adele (2013). 'Writing as Mirror. Origins and Identities in the Work of Brina Svit.' In Adele Parker and Stephenie Young, eds. Transnationalism and Resistance. Experience and Experiment in Women's Writing. Amsterdam/New York: Rodopi: $185^{-210 .}$

Phan, Peter C. (2012). 'World Christianity. Its Implications for History, Religious Studies, and Theology'. Horizons 39,2: 171-188.

Phan, Peter C. (2016). 'World Christianities. Transcontinental Connections'. The Journal of World Christianity 6,1: 205-215.

Radhakrishnan, Rajagopalan (2008). History, the Human, and the World Between. Durham \& London: Duke University Press.

Robbins, Joel (2014). 'The Anthropology of Christianity. Unity, Diversity, New Directions.' Current Anthropology 55: 157-71.

Robert, Dana L. (2000). 'Shifting Southward. Global Christianity since 1945' International Bulletin of Missionary Research 24,2: 51-58. 
Robert, Dana L. (2009). Christian Mission. How Christianity Became a World Religion. Chichester: Wiley and Blackwell.

Robert, Dana L. (2013). 'Witness and Unity in 21st Century World Christianity.' Transformations 30,4: 243-256.

Saner, Hans (1988). 'Jaspers' Idee einer kommenden Weltphilosophie.' In Leonard Ehrlich and Richard Wisser, eds. Karl Jaspers Today. Philosophy at the Threshold of the Future. Lanham: University Press of America: 75-92.

Sanneh, Lamin (2003). Whose Religion is Christianity? The Gospel beyond the West. Grand Rapids: Eerdmans.

Sanneh, Lamin (2008). Disciples of All Nations. Pillars of World Christianity. Oxford: Oxford University Press.

Satyavrata, Ivan (2004). “Glocalization" and Leadership Development for Transforming Mission in India.' Transformations 21, 4: 211-217.

Schreiter, Robert J. (1997). The New Catholicity. Theology between the Global and the Local. Maryknoll, N.Y.: Orbis Books.

Stanley, Brian (2004). 'Twentieth Century World Christianity. A Perspective from the History of Missions.' In Donald M. Lewis, ed. Christianity Reborn. The Global Expansion of Evangelicalism in the Twentieth Century. Grand Rapids: Eerdmans: $5^{2-83}$.

Stearns, Peter N. (2004). 'World History. Western Civilization and World History. Conflicts and Complements.' Historically Speaking. The Bulletin of the Historical Society 5,4:2-4.

Suh, Myung-Sahm (2015). 'Glocalization of "Christian Social Responsibility". The Contested Legacy of the Lausanne Movement among Neo-Evangelicals in South Korea.' Religions 6: 1391-1410.

Tagore, Saranindranath (2017). 'On the Concept of World Philosophy'. Philosophy East and West 67,2: 531-544.

Tan, Jonathan Y. and Anh Q. Tran, eds. (2016). World Christianity. Perspectives and Insights. Maryknoll: Orbis Books.

Taylor, Charles (1994). 'The Politics of Recognition.' In Amy Gutmann, ed. Multiculturalism. Princeton: Princeton University Press: $25^{-74}$.

Thangaraj, Thomas (2018). 'What in the World is World Christianity? http://www .bu.edu/cgcm/annual-theme/what-in-the-world-is-world-christianity/, date of access: 13 June, 2018.

Teoharova, Genoveva (2005). KarlJaspers'Philosophie auf dem Weg zur Weltphilosophie. Würzburg: Köningshausen \& Neumann.

Unesco (2006). Philosophy. Intersectoral Strategy on Philosophy. Paris: Unesco.

Ustorf, Werner (2010). Robinson Crusoe Tries Again. Missiology and European Constructions of "Self" and "Other" in a Global World 1789-2010. Göttingen: Vandenhoeck\& Ruprecht. 
Vanhaute, Eric (2013). World History. An Introduction. Abingdon: Routledge.

Wei, Maoping (2012). 'Ein neuer Versuch zu Goethes "Weltliteratur"-Begriff.' Literaturstraße 13: 43-48.

Walls, Andrew (2002). The Cross-Cultural Process in Christian History. Maryknoll: Orbis Books.

Werner, Dietrich et al., eds (2010). Handbook of Theological Education in World Christianity. Theological Perspectives, Ecumenical Trends, Regional Surveys. Oxford: Regnum.

Wild-Wood, Emma (2017). 'Relocating Unity and Theology in the Study of World Christianity.' In Joel Cabrita, David Maxwell and Emma Wild-Wood, eds. Relocating World Christianity. Interdisciplinary Studies in Universal and Local Expressions of the Christian Faith. Leiden: Brill: 324-342.

Xavier, Subha (2010). 'From Weltliteratur to Litterature-Monde. Lessons from Goethe for the Francophone World'. Contemporary French and Francophone Studies 14,1: 57-65. Xavier, Subha (2016). The Migrant Text. Making and Marketing a Global French Literature. Montreal: McGill Queen's University Press. 